\title{
The use of recycled waste products in a sustainable house design - a case study
}

\author{
Agnes Iringová ${ }^{1, *}$ \\ ${ }^{1}$ Department of Building Constructions and Urban Planning, Faculty of Civil Engineering, University \\ of Žilina, Univerzitná 1, 01026 Žilina, Slovakia
}

\begin{abstract}
The current state of waste production and management in Slovakia. Legislative regulations. Analysis of applying recycled waste products in the construction of sustainable buildings as a substitution of non-renewable materials. The comparison of the physical parameters of recycled materials with non-renewable materials in terms of thermal and fire protection. The construction solution of lightweight building envelopes with a timber supporting system using the thermal insulation and facing made of recycled materials. The model solution of a wood-based family house using recycled waste materials. The comparison of the environmental burden of a standard lightweight sandwich peripheral wall with a recycled waste wall.
\end{abstract}

\section{Introduction}

Due to the high consumption rate, there is an increasing production of municipal and construction waste in our society. Therefore it is of utmost importance to manage the waste properly. The considerable amount of municipal and construction waste is produced in the construction, operation, and demolition of buildings. It is also needful to look for the possibilities of waste reprocessing and reusing as building materials. The paper deals with the possibilities of using recycled waste materials in the construction of wood-based houses as an equivalent to commonly used non-renewable materials.

\section{Situation in the municipal waste processing and current legislation in Slovakia}

The bulk of municipal waste in Slovakia, about $88 \%$ of the total volume, is currently being dumped, landfilled, or incinerated. Slovakia is among the European countries with the lowest proportion of recycled or composted municipal waste - about $12 \%$ of its total production.

In Slovakia, there are about $320 \mathrm{~kg}$ of solid municipal waste per inhabitant every year. Besides, further $14 \mathrm{~kg}$ of industrial waste and $1 \mathrm{~kg}$ of hazardous waste must be added to

\footnotetext{
*Corresponding author: agnes.iringova@fstav.uniza.sk
} 
each kilogram of household waste generated by its production. About $0.4 \%$ of this is used as a secondary material, $0.8 \%$ is used in another way (compost), and $98.8 \%$ is disposed. This is a huge ecological problem because the percentage of waste recovery is desperately low, if compared to countries such as Germany, Belgium, or Sweden, where the waste recyclability is about $70-80 \%$. On average, about $44 \%$ of municipal waste is currently being recycled or composted in EU countries. The EU is striving for more efficient waste management so that the impact of its production on the quality of the environment and the health of the population is minimal. The aim of the European legislation is to achieve a circulating economy where products are not disposed or stored, but recycled and reused in the manufacturing process. By 2020, the percentage of waste recycling in EU countries should be increased to $50 \%$; by 2030 it should be $70 \%$, according to this legislation. Similarly, the proportion of dumped and landfilled waste that has a negative impact on the environment should also be reduced to five per cent.

In Slovakia, the new Act No. 79/2015 on waste has been in force since 2015. It clearly defines the priorities in the waste management in contrast to the the previous Act No. $223 / 2001$. The new legislative definitions such as waste stream, by-product, waste end, waste trader and broker have been incorporated into the new Act.

\section{Environmental burden of building materials}

Specification of the requirements for eco-friendly products is defined in the Regulation of the European Parliament and European Council No. 305/2011 [2] replacing the European Council Directive No. 89/106/EEC on construction products. The basic requirements for the buildings defined therein are supplemented by the new seventh requirement - the sustainable use of natural resources. This requirement is supported by a set of European Standards incorporated into Slovak legislation. [2] The standards for designing sustainable buildings are as follows: STN EN 15643-Part 1-4, STN EN 15942 (73 0911) Sustainable construction, Environmental product declarations, Communication Formats in the Business Environment (1 April 2012); STN EN 15804 (73 0912) Sustainable construction, Environmental product declarations, Basic rules for Building Products (1 August 2012); TNI CEN/TR 15941 (73 0910) Sustainable Construction, Environmental product declarations, Methodology for the selection and use of generic data (1 August 2010).

In general, the environmental burden of a product or material is determined by the consumption of built-in energy and emission production throughout the life cycle. The generally accepted equivalent for assessing the impact of a material or product on the

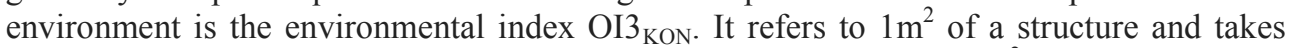
into account the third weights of eco-indexes applied on $1 \mathrm{~m}^{2}$ of construction. Generally accepted equivalent for assessing the impact of building materials and structures on the environment is the value of $\mathrm{CO} 2 \mathrm{ekv}$ emission production along with the assessment of primary energy tied, and, from the regional point of view, the value of SO2ekv emission production. OI3 calculates these three important categories of environmental protection for each squared meter of a building element on a scale 0 to 100 .

\section{Possibilities of applying recycled waste products in the construction of wood-based sustainable houses}

As for sustainable construction, the ecological optimization of building materials and products is especially important because the environmental burden relating to the building sector should be as low as possible, ideally within category A. This can be achieved by using recycled materials. The most common and easy available is wood and paper waste. 
The ordinary consumption of every human being produces a large proportion of municipal waste connected with the daily consumption of food - paper-based packaging or Tetra Pak beverage cartons. Another source of paper waste is printed matter, i.e. advertising leaflets, newspapers, magazines, and various other documents. All these products can be $100 \%$ recycled and reused for the production of building elements. They can be used, for example, in the construction of lightweight envelopes for timber structures. The recycling of wood waste could be similar. The recycled wood waste products can be used as part of thermo-insulating or facing panels in construction of lightweight sandwich building envelopes.

\subsection{Recycled paper panels}

The boards made of recycled municipal Tetra Pak waste can be used as interior facing panels. The production technology consists in grinding and pressing the waste under the high pressure and temperature into the shape of boards. The important fact is that no binding agents or chemical fillers are added to the base mixture, i.e. there is no environmental burden, and waste does not pollute the environment. The Slovak market currently offers Tetra Pak boards of size $2.700 \times 1.200 \mathrm{~mm}$ and thickness up to $20 \mathrm{~mm}$. The boards are made from a crushed polyethylene (PE) and have a paper cover layer. Their utility and physical parameters are comparable to the commonly used material such as plasterboards or cement-wood boards. They are re-recyclable after the lifetime period.

They are classified as flammable within Class E in terms of fire protection. If they are double-layered $2 \times 10 \mathrm{~mm}$, they are fire resistant up to 30 minutes according to the manufacture's certificate; they meet the fire resistance requirements for fire- separation structures in family houses.

\subsection{Recycled wood panels}

The wood fibre boards are produced from wood fibres with the addition of aluminium sulphate and reinforcing fillers or other additives, e.g. hydrophobized additions of water glass and paraffin. These boards have a volume density of $250-300 \mathrm{~kg} / \mathrm{m}^{3}$, compressive strength of about $200 \mathrm{kPa}$, and tensile strength of about $30 \mathrm{kPa}$. They can be used as a facing interior or exterior material fastened on wooden grids.

\subsection{Thermal insulations made of recycled paper}

Blown cellulose is a paper mixture made by paper recycling. It is produced with the addition of borate salts, magnesium sulphate, and ammonium phosphate. These additives make it more resistant to fire, moulds, and fungi as well as repel insects and small rodents. The material has a similar thermal capacity as the wood fibre products $\mathrm{c}=2000 \mathrm{~J} / \mathrm{kg} \cdot \mathrm{K}$.

\subsection{Thermal insulation made of recycled wood}

The soft wood fibre boards with low volume density up to $50 \%$ can be used as thermoinsulating filler between post-mounted timber panels of building envelopes. They are produced using wood fibres with the addition of aluminium sulphate, reinforcing fillers, or other additives. 
Table 1 Comparison of physical parameters of recycled waste products with commonly used ones

\begin{tabular}{|l|c|c|c|c|c|c|}
\hline \multirow{2}{*}{$\begin{array}{l}\text { Physical } \\
\text { properties }\end{array}$} & \multicolumn{3}{|c|}{ Heat insulation } & \multicolumn{3}{c|}{ Facing boards } \\
\cline { 2 - 7 } & \multicolumn{2}{|c|}{ Recycled materials } & $\begin{array}{l}\text { Standard } \\
\text { materials }\end{array}$ & \multicolumn{2}{c|}{ Recycled materials } & $\begin{array}{l}\text { Standard } \\
\text { materials }\end{array}$ \\
\cline { 2 - 7 } & $\begin{array}{l}\text { Soft } \\
\text { fibreboard } \\
140 \mathrm{~mm} \\
\text { thick }\end{array}$ & $\begin{array}{l}\text { Blown } \\
\text { cellulose } \\
140 \mathrm{~mm} \\
\text { thick }\end{array}$ & $\begin{array}{l}\text { Mineral } \\
\text { wool } \\
140 \mathrm{~mm} \\
\text { thick }\end{array}$ & $\begin{array}{l}\text { Hard } \\
\text { fibreboard } \\
60 \mathrm{~mm} \\
\text { thick }\end{array}$ & $\begin{array}{l}\text { TETRA K } \\
\text { board } \\
15 \mathrm{~mm} \\
\text { thick }\end{array}$ & $\begin{array}{l}\text { Gypsum } \\
\text { plasterboard } \\
15 \mathrm{~mm} \\
\text { thick }\end{array}$ \\
\hline $\begin{array}{l}\text { Density } \\
\rho\end{array}$ & $\begin{array}{c}50 \\
\mathrm{~kg} / \mathrm{m}^{3}\end{array}$ & $\begin{array}{l}30-60 \\
\mathrm{~kg} / \mathrm{m}^{3}\end{array}$ & $\begin{array}{c}18 \\
\mathrm{~kg} / \mathrm{m}^{3}\end{array}$ & $\begin{array}{l}250-300 \\
\mathrm{~kg} / \mathrm{m}^{3}\end{array}$ & $\begin{array}{c}850 \\
\mathrm{~kg} / \mathrm{m}^{3}\end{array}$ & $\begin{array}{c}900 \\
\mathrm{~kg} / \mathrm{m}^{3}\end{array}$ \\
\hline $\begin{array}{l}\text { Thermal } \\
\text { conductivity } \\
\text { coefficient } \lambda\end{array}$ & $\begin{array}{c}0.039- \\
0.045\end{array}$ & $\begin{array}{c}0.040- \\
\mathrm{W} / \mathrm{mK}\end{array}$ & $\begin{array}{c}0.038 \\
\mathrm{~W} / \mathrm{mK}\end{array}$ & $\begin{array}{c}0.040- \\
0.055 \\
\mathrm{~W} / \mathrm{mK}\end{array}$ & $\begin{array}{c}0.146 \\
\mathrm{~W} / \mathrm{mK}\end{array}$ & $\begin{array}{c}0.25 \\
\mathrm{~W} / \mathrm{mK}\end{array}$ \\
\hline $\begin{array}{l}\text { Diffusion } \\
\text { resistance } \\
\text { factor }\end{array}$ & $\mu=1-2$ & $\mu=1-3$ & $\mu=1$ & $\mu=5-10$ & $\mu=10$ & $\mu=90$ \\
\hline $\begin{array}{l}\Delta \text { OI3 } \\
\text { Pkt } / \mathrm{m}^{2}\end{array}$ & 5.6 & 6.0 & 8.4 & 6 & 0.1 & 4 \\
\hline $\begin{array}{l}\text { Reaction to } \\
\text { fire class }\end{array}$ & $\mathrm{E}$ & $\mathrm{C}-\mathrm{E}$ & $\mathrm{B}$ & $\mathrm{E}$ & $\mathrm{E}$ & $\mathrm{A}$ \\
\hline
\end{tabular}

\section{Environmental burden of timber sandwich structures made of recycled materials in a model solution of a wood-based family house}

\subsection{Model solution of a family house and the composition of a building envelope made of recycled paper and wood materials}

The model family house is constructed as a lightweight single-storey wood-based sustainable structure. The building envelope was constructed using the building materials made of recycled waste. The model facing compositions are made of recycled raw materials - wood waste and Tetra Pak cartons. The thermal insulation is made of blown cellulose or recycled paper and wood waste - sawdust. Such insulation has very good thermo-insulating properties at low eco-index value. The layout and construction solution of the house is shown in Fig. 1; the three variants of the building envelope compositions are given in Table 2. 


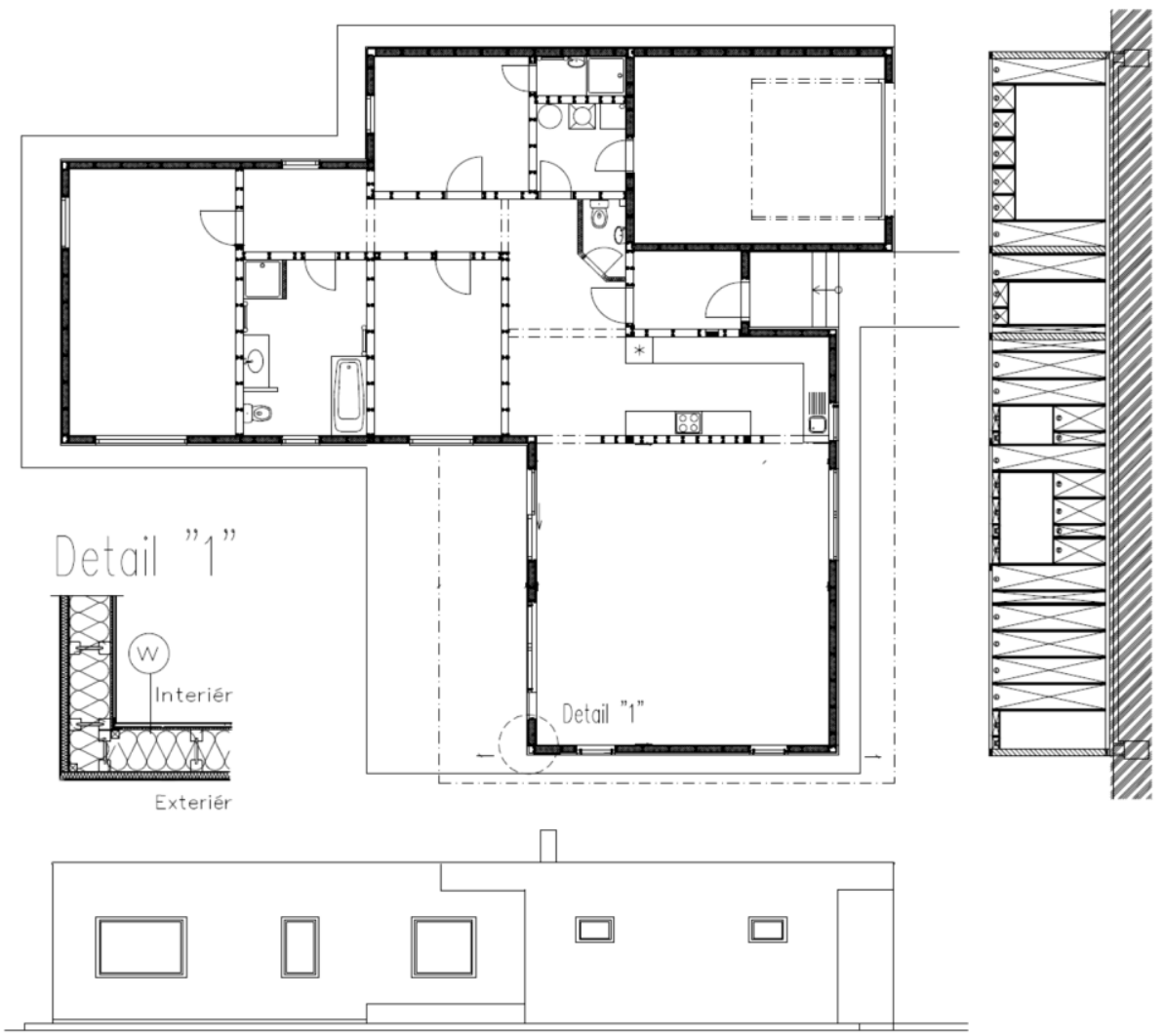

Fig. 1. Geometry and layout solution of the model family house

Table 2 Construction solutions and physical parameters of the construction compositions in the model family house

\begin{tabular}{|c|c|c|c|c|c|c|c|}
\hline & $\begin{array}{l}\text { Type of a layer } \\
\text { (inside to outside) }\end{array}$ & $\begin{array}{c}\text { Thickness } \\
{[\mathrm{mm}]}\end{array}$ & $\begin{array}{c}\rho \\
{\left[\mathrm{kg} / \mathrm{m}^{3}\right]}\end{array}$ & $\begin{array}{c}\lambda \\
W / m K\end{array}$ & \begin{tabular}{|l}
$\mathbf{R}$ \\
$\mathbf{m}^{2} \mathrm{~K} / \mathrm{W}$
\end{tabular} & $\begin{array}{c}\Delta \mathrm{OIJ3} \\
\mathrm{Pkt} / \mathbf{m}^{2}\end{array}$ \\
\hline \multirow{11}{*}{$\begin{array}{l}\text { Standard } \\
\text { solution }\end{array}$} & \multirow{11}{*}{$\begin{array}{l}\text { Wall 1 } \\
\text { Glass } \\
\text { wool }\end{array}$} & Gypsum plasterboard & 15 & 900 & 0.25 & 0.06 & 4 \\
\hline & & 90\% Glass wool MW & 60 & 18 & 0.038 & 1.57 & 6 \\
\hline & & $\begin{array}{l}10 \% \text { Timber }- \text { frame } \mathrm{a}^{\prime}= \\
625 \mathrm{~mm}\end{array}$ & $(60 / 40)$ & 475 & - & - & 0 \\
\hline & & $\begin{array}{l}\text { Polyethylene (PE) vapour } \\
\text { brake }\end{array}$ & 1 & - & 0.5 & 0 & 5 \\
\hline & & OSB boards & 18 & 650 & 0.13 & 0.14 & 4 \\
\hline & & $80 \%$ Glass wool MW & 140 & 18 & 0.038 & 3.68 & 8.4 \\
\hline & & $\begin{array}{l}20 \% \text { Timber }- \text { frame } \mathrm{a}^{\prime}= \\
625 \mathrm{~mm}\end{array}$ & $(140 / 60)$ & 475 & - & - & -1 \\
\hline & & OSB boards & 18 & 650 & 0.13 & 0.14 & 4 \\
\hline & & Mineral adhesive & 5 & - & 1.0 & 0.01 & 3 \\
\hline & & $\begin{array}{l}\text { Mineral thermo-insulating } \\
\text { panel }\end{array}$ & 80 & 112 & 0.044 & 1.8 & 9.5 \\
\hline & & $\begin{array}{l}\text { Silicate plaster with } \\
\text { synthetic resin additive, } \\
\text { reinforced }\end{array}$ & 5 & - & 0.8 & 0.01 & 9 \\
\hline
\end{tabular}




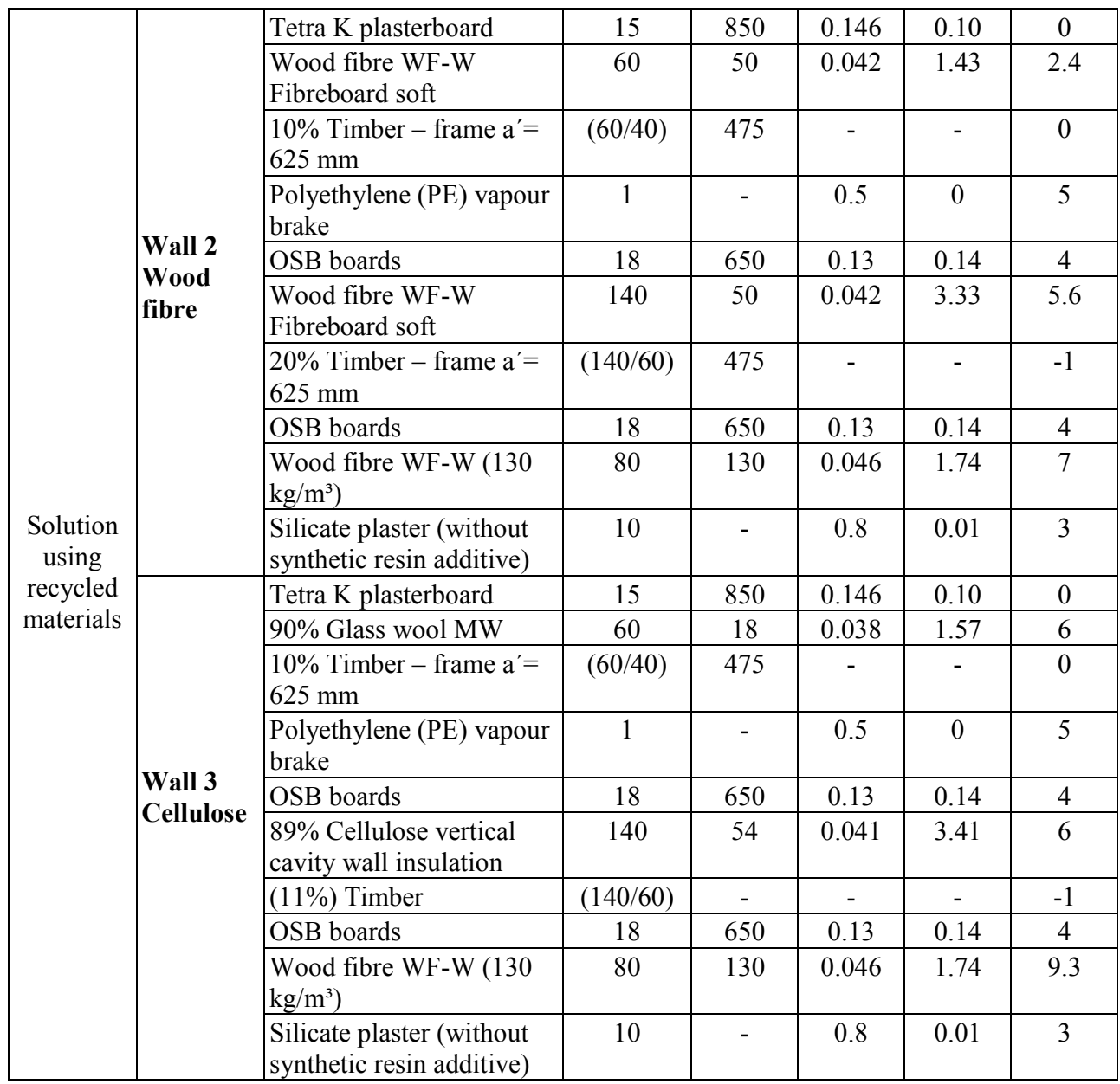

\section{$\Delta 013 \mathrm{Pkt} / \mathrm{m}^{2}$}

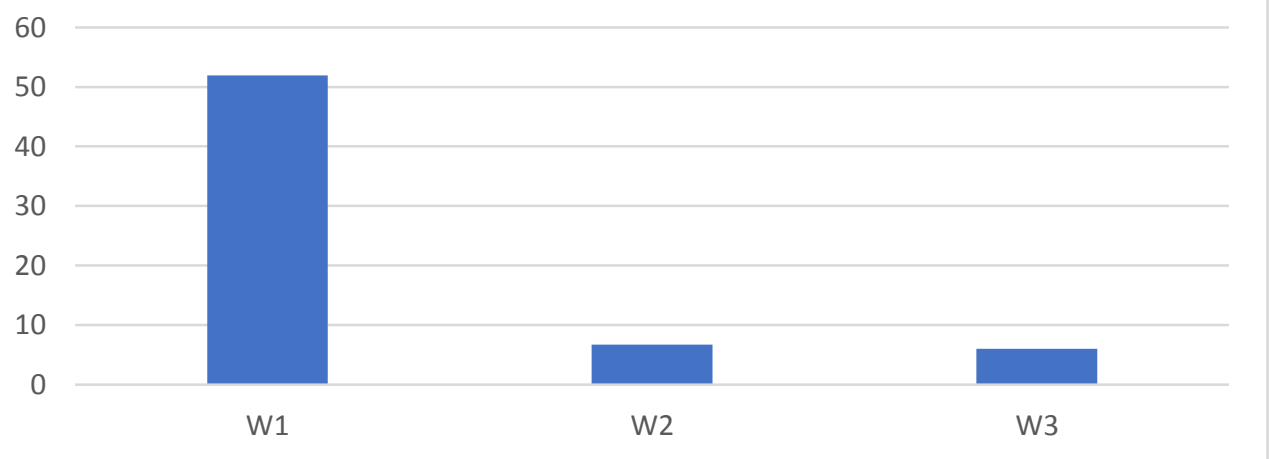

Fig. 2. Environmental burden of the building envelope in the model solution 


\section{Conclusions}

The construction of buildings in the current building standard has a negative impact on the environment. In terms of sustainable construction, it is important to optimize the building materials and products in such a way that their environmental burden would be as low as possible, ideally within the category A.

It will be necessary to use more recycled waste products in the future as the natural resources of raw materials are being increasingly depleted. Growing environmental awareness in our society means that the recycled materials will become one of main sources of input raw materials for the building industry. Waste recovery, both material and energy, will play an important role in waste treatment and management. Waste recycling and the development of waste industry is a significant step not only for the protection of the environment, but also for the sustainable development in the future.

The paper presents results of the project VEGA 1/0945/16.

\section{References}

1. Oekoindex component evaluation, Guideline for the ecological evaluation of component constructions by means of eco-index V1.4, Energy Institute Vorarlberg, Dornbirn, September 201

2. Durica P.: Poruchy budov - diagnostika a sanácia - 1. vyd. - Žilina : Žilinská univerzita, 244 s., [17,76 AH; 18,20 VH] : ISBN 978-80-554-0561-2 (2012)

3. Makovická -Osvaldová, L. - Gašpercová, S., The evaluation of flammability properties regarding testing methods, Civil and Environmental Engineering: scientific technical journal

4. Katunský D., Zozulák M., Lopušniak M., Bagoňa M., Katunská J., External brick wall and window detail in test cell in winter, International Journal of Civil Engineering and Technology, 9, (2018)

5. Katunský D., Katunská J., Alternative Solutions of Wooden External Walls-Case Study, ABCM Advanced Building Constructions and Materials, (At Lednice, Czech Republic, 2016)

6. Lokaj, A. et al.: Wooden houses and structures, Volume I, II. (in Czech). (CERM, Brno, 2010)

7. www.baubook.at 